Primljen / Received: 25.9.2012.

Ispravljen / Corrected: 21.12.2012.

Prihvaćen / Accepted: 27.12.2012.

Dostupno online / Available online: 15.1.2013.

\section{Hardness distribution over cross-section of grooved rails}

Authors:

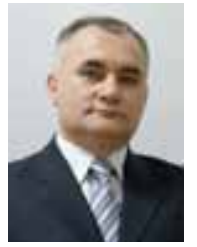

Prof. Stjepan Lakušić, PhD. CE

University of Zagreb

Faculty of Civil Engineering

Department for Transportation Engineering laki@grad.hr

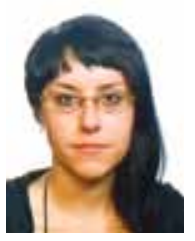

Maja Ahac, MCE

University of Zagreb

Faculty of Civil Engineering

Department for Transportation Engineering mahac@grad.hr

Stjepan Lakušić, Maja Ahac

\title{
Hardness distribution over cross-section of grooved rails
}

Head hardened rails have been introduced In order to extend the rail-replacement cycles for Zagreb tram tracks. During their precurving, the rail cracking occurred. Hardness tests were performed and tensile strength was calculated to establish whether unusual mechanical properties of rail steel are responsible for the cracking. Tests have shown that hardness values, despite significant variation over the rail cross-section, are higher than the prescribed minimum. It is assumed that rail problems encountered may be due to changes in rail steel microstructure resulting from an increase in rail head hardness during its thermal treatment.

Key words:

grooved rails; rail head hardening; hardness measurements; tensile strength

Izvorni znanstveni rad

Stjepan Lakušić, Maja Ahac

\section{Raspodjela tvrdoće u poprečnom presjeku žljebaste tračnice}

Radi produljenja ciklusa zamjene tračnica na zagrebačkim je tramvajskim kolosijecima uvedena primjena tračnica s povećanom tvrdoćom glave. Prilikom savijanja takvih tračnica, za potrebe ugradnje u krivinama, došlo je do njihova pucanja. Kako bi se utvrdilo leži li razlog u neuobičajenim mehaničkim karakteristikama čelika tračnica, provedena su mjerenja tvrdoće temeljem kojih se proračunski definirala vlačna čvrstoća. Ispitivanja su pokazala da su izmjerene vrijednosti tvrdoće, iako znatno variraju duž poprečnog presjeka tračnice, veće od propisanih minimalnih vrijednosti. Može se pretpostaviti da problemi vezani uz ove tračnice mogu biti posljedica promjena u mikrostrukturi čelika zbog povećanja tvrdoće glave tračnice njezinom termičkom obradom.

Ključne riječi:

žljebaste tračnice, povećanje tvrdoće glave tračnice, mjerenja tvrdoće, vlačna čvrstoća

Wissenschaftlicher Originalbeitrag

Stjepan Lakušić, Maja Ahac

\section{Härteverteilung im Querschnitt von Rillenschienen mit erhöhter Kopfhärte}

Mit dem Ziel die Häufigkeit des Schienenersatzes im Strassenbahnnetz der Stadt Zagreb zu reduzieren, sind Schienen mit erhöhter Kopfhärte eingeführt worden, bei deren Vorbiegung jedoch wiederholt Bruchbeschädigungen aufgetreten sind. Um die entsprechenden Ursachen zu ermitteln und einen möglichen Zusammenhang mit den außergewöhnlichen mechanischen Stahleigenschaften festzustellen, sind Messungen der Schienenhärte und Berechnungen der zugehörigen Zugfestigeit durchgeführt worden. Die ermittelte Härte weist zwar deutliche Abweichungen entlang des Querschnitts vor, liegt jedoch über den vorgegebenen Minimalwerten. Die auftretenden Mängel der Schienen können durch die Veränderung der Stahlstruktur, aufgrund der thermischen Bearbeitung zum Erzielen erhöhter Kopfhärte, bedingt sein. 


\section{Introduction}

Rails are crucial and most expensive elements of the track structure. They are the point of contact between the track and vehicle wheels, and they serve as continuous structural beams that transmit vehicle load onto lower parts of the track structure. Their main objectives are to ensure safe guidance of rail vehicles, and to maximise safe and comfortable use of the track.

The vehicle load is transferred onto lower components of the track structure (fastening systems, sleepers, etc.) at the wheel-rail contact. Due to continuous change of contact areas (reduction followed by increase) between components of the vehicle-track dynamic system, the distribution of forces is operated according to the "sandglass" form [1]. The vehicle body transfers the load via bogies and wheels onto the rail, gradually increasing the stresses. In case of Zagreb tram tracks, stresses at the wheel-rail contact can attain up to $350 \mathrm{~N} / \mathrm{mm}^{2}$. These stresses eventually cause deteriorating reactions in the wheel and rail material, which are deformed and their mechanical properties are altered. This brings up the issue of how material properties influence the dynamic vehicle-track system behaviour during the track use.

Due to rail-wheel interaction forces, the rail head is continuously exposed to abrasive wear during operation of railway traffic. Vertical rail head wear occurs in straight sections of the track. An additional running surface wear occurs in curves. The wear rate depends on the quality of rail steel, which is defined by its hardness. The rail steel hardness must ensure satisfactory wear of the rail head, and hence conventional track maintenance cycles. Experience has shown that the maximum prescribed rail wear in smallradius curves occurs before formation of fatigue cracks, while the opposite is true at straight sections of the track. The rail head wear rate in small radius curves can be as many as ten times higher, when compared to the wear at straight track sections [2]. For this reason, straight sections of tram tracks in Zagreb consist of grooved rails made of normal grade steel with a minimum tensile strength ( $\mathrm{fu}$ ) of $680 \mathrm{~N} / \mathrm{mm}^{2}$ and Brinelli hardness of $200 \mathrm{HBS}$, while in curved sections, and at switches and crossings, the wear-resistant rails with a minimum tensile strength ( $\mathrm{fu}$ ) of $880 \mathrm{~N} / \mathrm{mm}^{2}$ and Brinelli hardness of $260 \mathrm{HBS}$, are used.

Due to high vertical and/or gauge face rail head wear rate, tracks subjected to very high traffic load, such as the tram tracks in Zagreb (individual tram lines in the city centre are exposed to traffic of 15 million gross tons a year, with the tram vehicle passing frequency of under one minute [3]), and also tracks with high share of small radius curves $(R \min \geq 18 m)$, often call for premature rail replacement. Rail replacement at places where tram corridor is also used by other traffic (Fig.1) represents the biggest maintenance issue for the Zagreb Municipal Transit System - ZET Ltd. At these locations, where tram tracks are embedded either in asphalt or in precast concrete plates [4], the organisation of track reconstruction while ensuring an undisturbed operation of other traffic is very complicated if not impossible. In order to extend the rail replacement cycles for Zagreb tram track structures, head hardened $(\mathrm{HH})$ rails have been introduced. There are two main methods of $\mathrm{HH}$ rail production: by making modifications in chemical composition of the standard carbon rail steel, or by heat treatment of the rail head (Figure 2. [5]). Foreign experience in the $\mathrm{HH}$ rail use shows that increase in rail steel hardness at the wheel-rail contact is a highly efficient and cost-effective method for extending the rail life cycle, because the wear resistance of rails is in that case increased by as many as three times [6]. This positive experience in $\mathrm{HH}$ rail use was severely compromised after the ZET Ltd. purchased heat treated HH Ri-60 rails, steel grade 700 and $900 \mathrm{~A}$, for which the qualifying test results, provided by the manufacturer, showed satisfactory values of rail steel mechanical properties. First problems occurred during rail precurving (rails were cracking). Rails that were installed in the tracks soon showed significant signs of wear. According to agreement with ZET Ltd., the Ministy of Transport conducted its own tests in order to

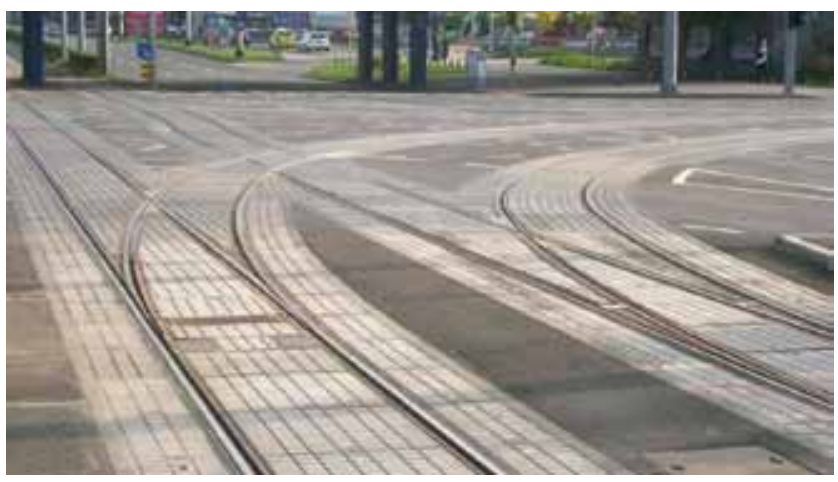

Figure 1. Standard tram track structure in Zagreb

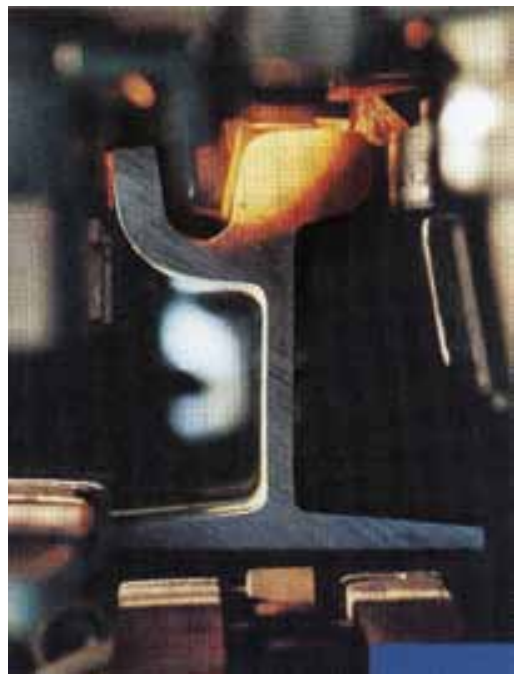

Figure 2. Heat treatment of the grooved rail head [5] 
either confirm or reject qualifying test results, i.e. to check whether mechanical properties of the steel are responsible for increased brittleness and accelerated wear of these rails.

\section{Analysis of mechanical properties}

Hardness tests were conducted in order to define mechanical properties of the grooved rail steel. Although hardness is not a precisely defined mechanical feature, its measurement has been established as one of the most common procedures in the field of material properties investigation. The reasoning behind this assertion is that the hardness test is easier and much faster to perform than other mechanical properties test methods. It does not require specially tailored samples - testing can be performed either on intermediate or final products. Also, a big advantage is the relatively simple correlation between hardness and tensile strength.

For testing purposes, four new $\mathrm{HH}$ rails (two of steel grade 700 and two of steel grade 900A) were selected using the random sampling method. Ten millimetres thick slices were cut at the distance of one meter from rail ends. Then they were polished and marked according to rail steel grade and ordinal number, as follows: 700-1, 700-2, 900A-1 and 900A2. Hardness measurements were conducted using the Brinell test [7].

\subsection{Prescribed minimum mechanical properties}

In case of $\mathrm{HH}$ rails, mechanical properties of steel at rail web and base must comply with prescribed values for the basic steel grade given in Table $1[7,8]$, while the steel in the head area (Figure 3 ) must meet additional requirements shown in Table 2 [9].

\subsection{Rail head hardness measurements}

Hardness measurements were conducted at measurement points 1 and 2 of the rail head defined by [9], at three additional points at the running surface (marked as $\mathrm{Ha}$ and $\mathrm{Hb}$ ), and at the rail guide (G) (Figure 3 and 4). Measurement points marked as $1 \mathrm{a}, 1 \mathrm{~b}$, and $1 \mathrm{c}$ are located $10 \mathrm{~mm}$ below the running surface, which is the zone of maximum tangential stresses in the rail cross-section. The measurement point $2 \mathrm{a}$ location corresponds to the location of sampling for the tensile strength testing. In total, more than a hundred hardness measurements were carried out at these measurement points.

An overview of mean hardness values, calculated on the basis of values measured at the points 1 and 2 , as related to prescribed minimum values given in Table 2 , is given in Figure 5. The difference between the mean and prescribed minimum hardness values for each measurement point, expressed as percentage, is given in Figure 6. It can be seen that all mean hardness values are greater than prescribed minimum values, with an average $25 \%$ increase in hardness. The biggest difference in all four cases was observed at the measurement point $2 \mathrm{c}$, where mean hardness values exceed the prescribed minimum by $33 \%$ (samples 700 ) or $26 \%$ (samples $900 A$ ).

An overview of the mean hardness values, based on values measured at the running surface of the rail head and the guide, is given in Figure 7. In case of samples 900A, none of the mean values met the prescribed requirements (Figure 8). However, this unduly low hardness values at running surfaces have been neglected, as measurements were preformed on rail samples that were not in service and therefore their running surfaces were not subjected to cold forging.

Table 1. Minimal prescribed mechanical properties of rail steel grade 700 and $900 \mathrm{~A}$

\begin{tabular}{|c|c|c|c|c|c|c|c|}
\hline \multirow{3}{*}{ Sample } & \multicolumn{3}{|c|}{ Types of steel rails } & \multirow{3}{*}{$\begin{array}{c}\begin{array}{c}\text { Tensile } \\
\text { strength }\end{array} \\
\mathrm{R}_{\mathrm{m}}\left[\mathrm{N} / \mathrm{mm}^{2}\right]\end{array}$} & \multirow{3}{*}{$\begin{array}{l}\text { Elongation } \\
\qquad A_{5}[\%]\end{array}$} & \multirow{2}{*}{\multicolumn{2}{|c|}{$\begin{array}{c}\text { Approximate hardness range } \\
\text { at running surface }\end{array}$}} \\
\hline & \multirow{2}{*}{ Steel quality } & \multicolumn{2}{|c|}{ Steel grade } & & & & \\
\hline & & UIC $860 \mathrm{~V}$ & EN 13674-1 & & & UIC $860 \mathrm{~V}$ & EN 13674-1 \\
\hline $\begin{array}{l}700-1 \\
700-2\end{array}$ & normal & 700 & R 200 & $680-830$ & 14 & $200-245$ & $200-240$ \\
\hline $\begin{array}{l}900 A-1 \\
900 A-2\end{array}$ & wear resistant & $900 \mathrm{~A}$ & R 260 & $880-1030$ & 10 & $262-304$ & $260-300$ \\
\hline
\end{tabular}

Table 2. Minimum prescribed mechanical properties of $\mathrm{HH}$ rail steel grade 700 and $900 \mathrm{~A}$

\begin{tabular}{|c|c|c|c|c|c|c|}
\hline \multirow{2}{*}{ Sample } & Steel grade & Tensile strength & Elongation & $\begin{array}{c}\text { Min. hardness } \\
\text { at running surface }\end{array}$ & $\begin{array}{c}\text { Min. hardness } \\
\text { at position 1 }\end{array}$ & $\begin{array}{c}\text { Min. hardness } \\
\text { at position 2 }\end{array}$ \\
\cline { 3 - 7 } & $\mathrm{R}_{\mathrm{m}}\left[\mathrm{N} / \mathrm{mm}^{2}\right]$ & $\mathrm{A}_{5}[\%]$ & {$[\mathrm{HBS}]$} & 260 & 250 \\
\hline $\begin{array}{c}700-1 \\
700-2\end{array}$ & $700(\mathrm{R} 200)$ & 880 & $\geq 14$ & 270 & 320 & 300 \\
\hline $\begin{array}{l}900 \mathrm{~A}-1 \\
900 \mathrm{~A}-2\end{array}$ & $900 \mathrm{~A}(\mathrm{R} 260)$ & 1175 & $\geq 12$ & 330 & 3 \\
\hline
\end{tabular}




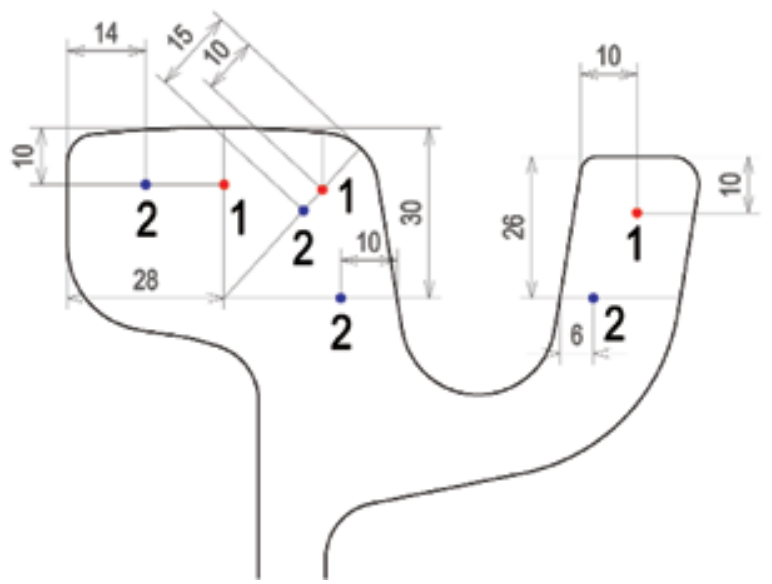

Figure 3. Positions of hardness measurements in the head hardened rail cross section [9]

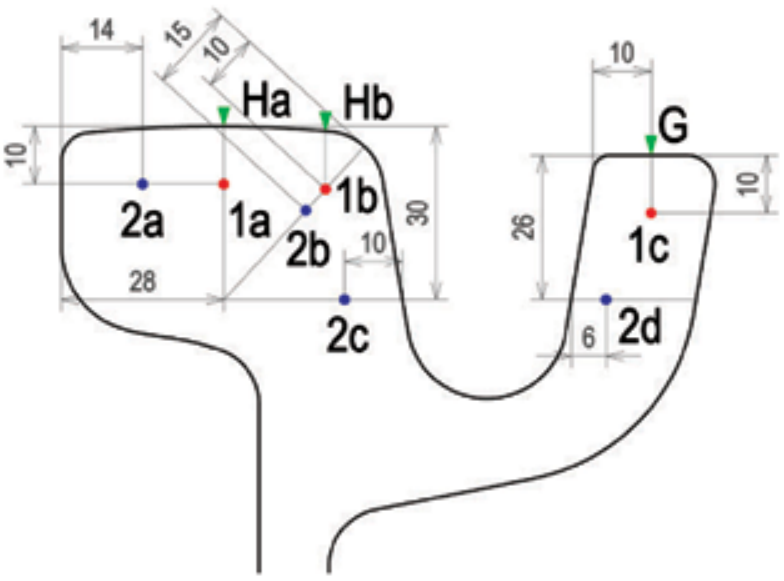

Figure 4. Rail head hardness measurement points and on the rail running surface

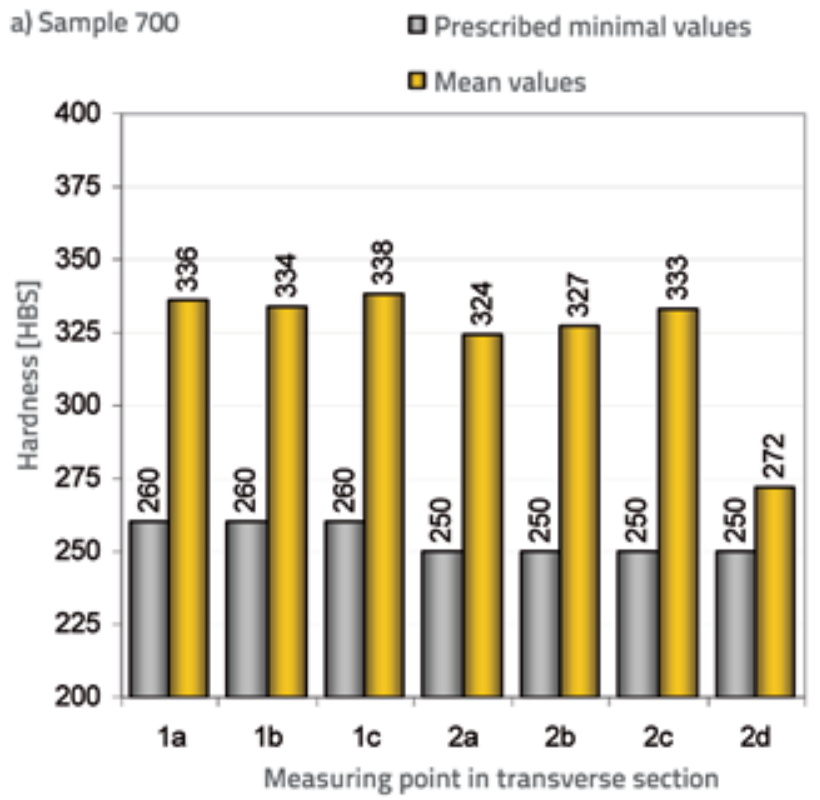

Cold forging induces hardening of the rail running surface due to continuous passing of vehicle wheels. The increase in hardness values depends on the magnitude of the total travel load, axle load, rail steel quality, wheel radius, etc. In order to define the actual values of hardness increase at the rail running surface, the Ministry of Transport conducted, in consultation with ZET Ltd., hardness testing of $\mathrm{HH}$ rails type $\mathrm{Ri}-60$ (steel grade $900 \mathrm{~A}$ ) at the tram track in curve. Measurements were made just before the track was put to regular use, and also one month later, i.e. after it was subjected to 0.5 million gross tones load. Measurements were made at six sections on the running surface of the outer and inner rail of the curve. Results showed that after a month of use, hardness values on the rail running surface increases, on an average, for 39 HBS (13\%) due to cold forging (Figure 9). As expected, the greater increase in hardness occurs at outer rail as it is more exposed to load. The results of this investigation lead to the conclusion that, if the rails had been in operation, the process of cold forging would have caused such an increase in the running surface hardness that would be compliant with the required minimum values.

The comparison of the mean hardness values at the running surface of the rails, and at measurement points $10 \mathrm{~mm}$ below the running surface, is shown in Figure 10. Mean hardness values $10 \mathrm{~mm}$ under the running surface are far greater than the mean hardness values at the running surface. Differences between these mean hardness values, and an increase of hardness under the running surface, are shown in Figure 11 for each sample. The analysis of results showed that the hardness values measured $10 \mathrm{~mm}$ under the surface are, on an average,

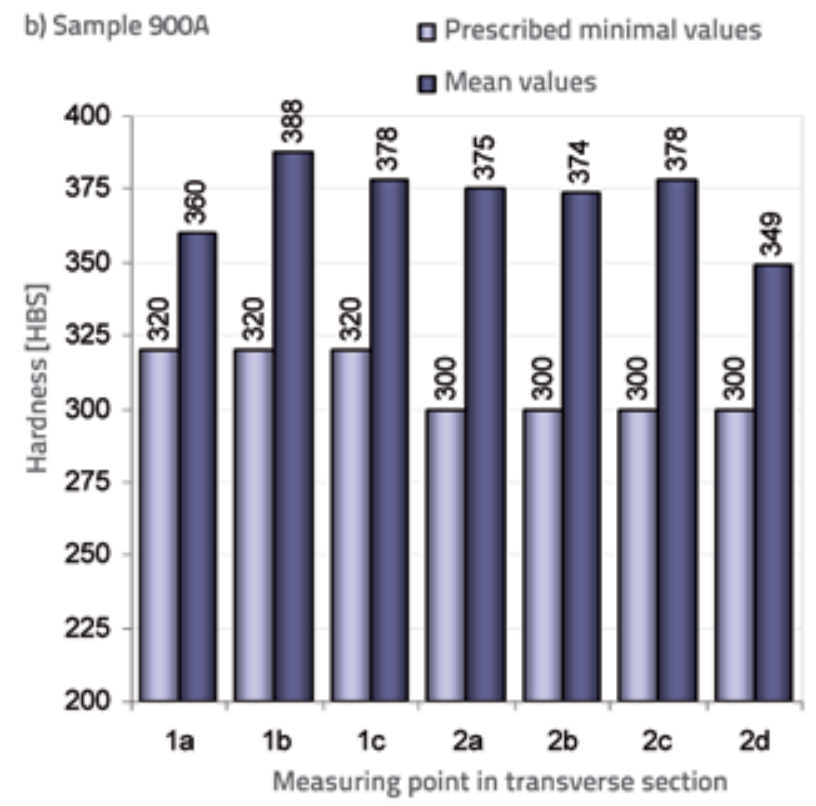

Figure 5. Mean hardness values at the rail head cross-section: a) samples 700-1 and 700-2; b) samples 900A-1 and 900A-2 
higher by $22 \%$ (samples 700 ) and $25 \%$ (samples $900 \mathrm{~A}$ ) when compared to hardness values on the running surface. Due to large variation in hardness values across a very small area of cross section (with the depth of only $10 \mathrm{~mm}$ ), a new set of measurements was made in order to define the actual distribution of hardness values across the entire cross-section of rail samples.

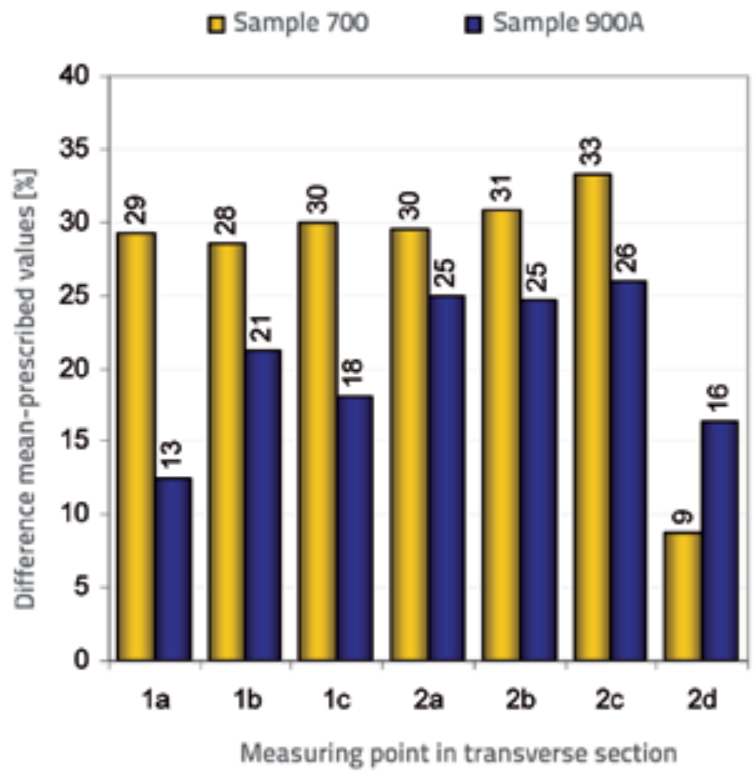

Figure 6. Difference between the mean and prescribed minimum hardness values at the rail head cross-section a) Increase in rail running surface hardness [HBS]

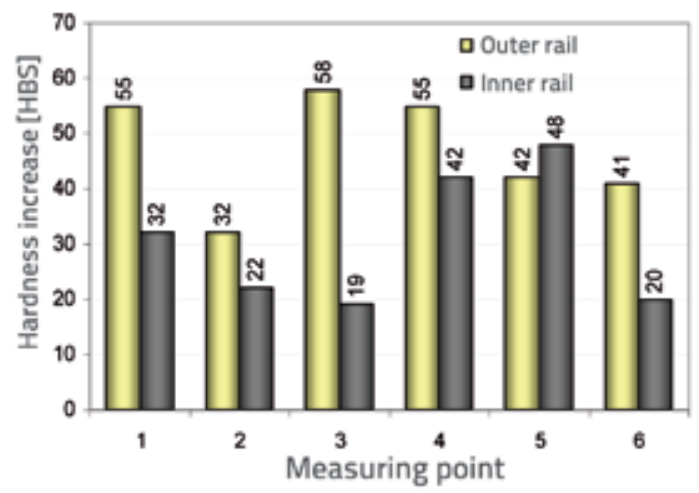

b) Increase in rail running surface hardness [\%]

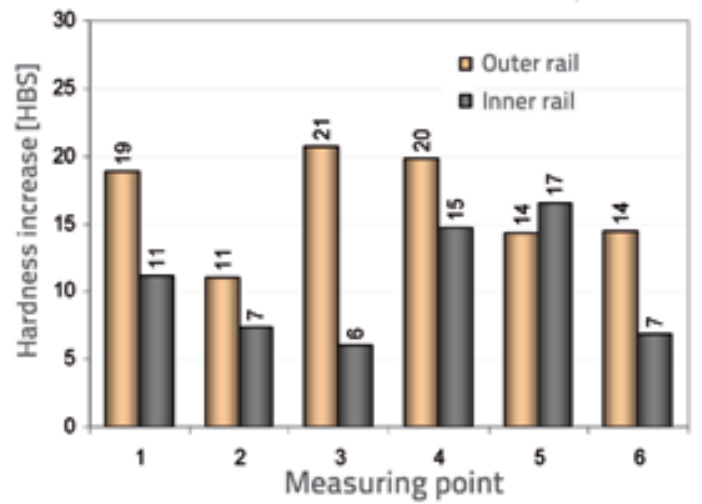

Figure 9. Increase in the rail running surface hardness due to cold forging

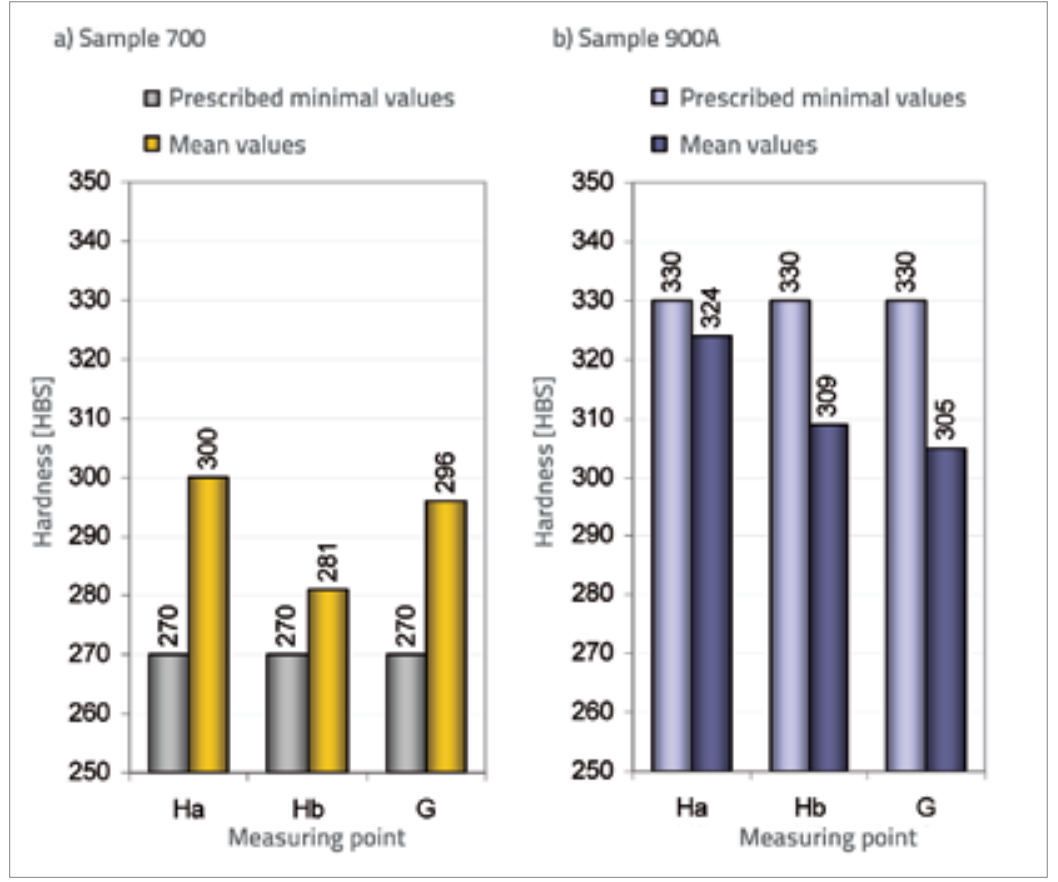

Figure 7. Mean hardness values calculated at the running surface: a) samples 700-1 and 700-2; b) samples $900 \mathrm{~A}-1$ and $900 \mathrm{~A}-2$

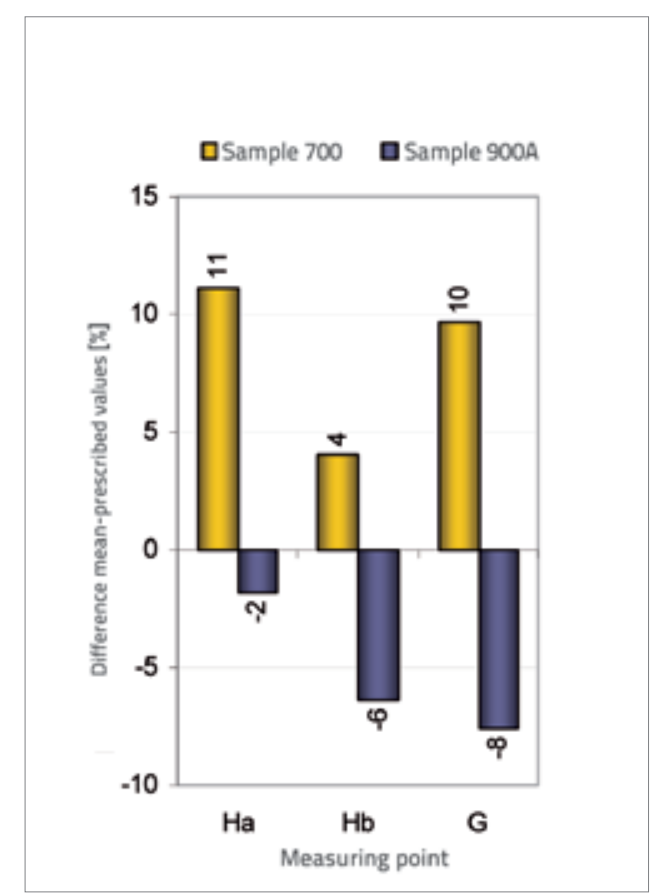

Figure 8. Difference between the mean and prescribed hardness values at the running surface 


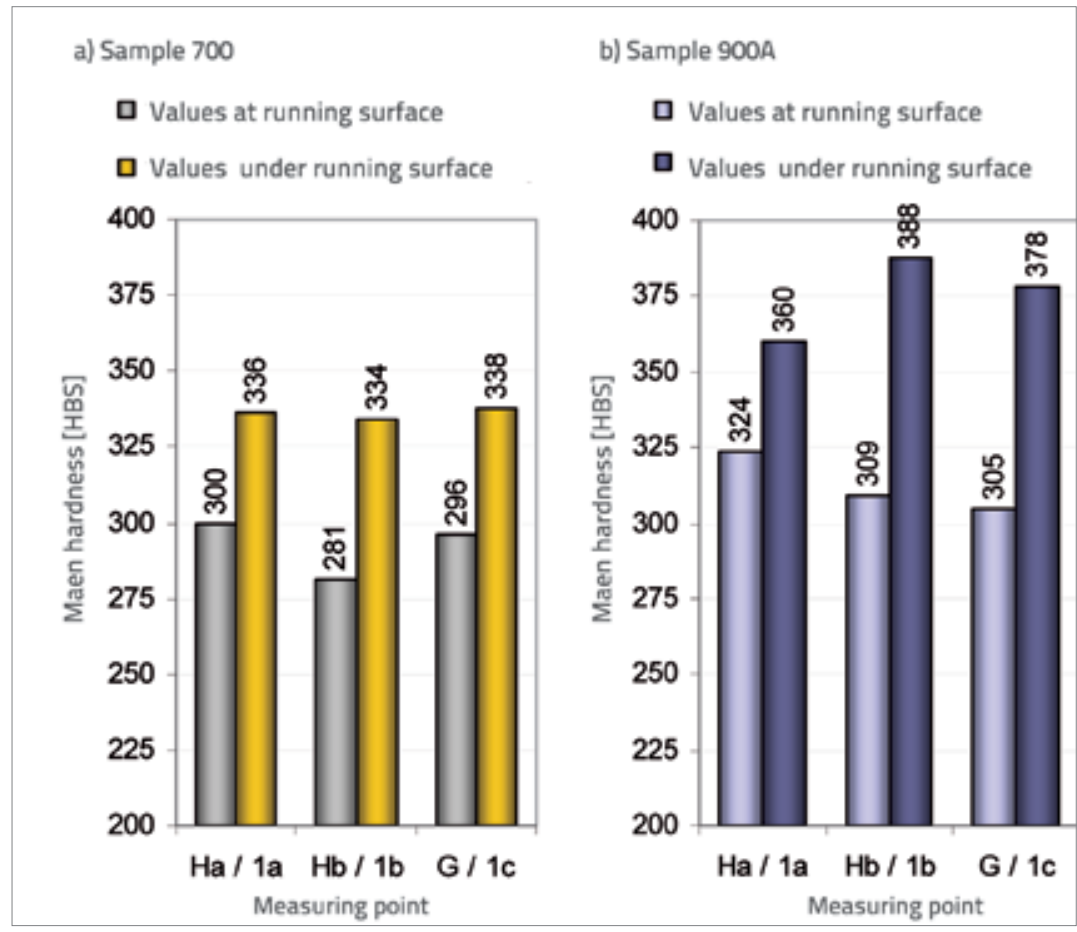

Figure 10. Comparison of mean hardness values at the running surface and $10 \mathrm{~mm}$ under the running surface: a) samples 700-1 and 700-2; (b) samples 900A-1 and 900A-2

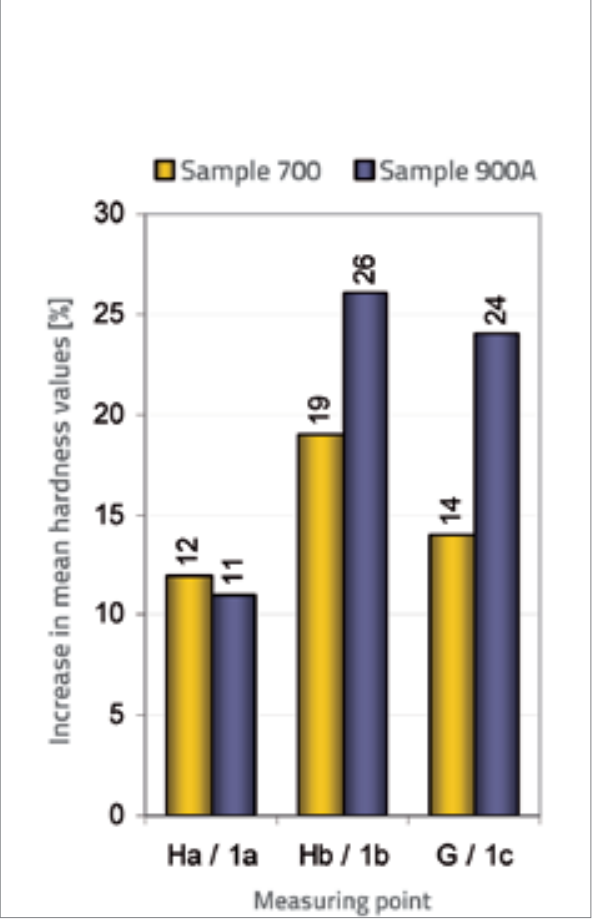

Figure 11. Increase in mean hardness values from running surface to $10 \mathrm{~mm}$ under the surface

\subsection{Hardness measurements at cross-section of grooved rail}

Hardness measurements were conducted at 285 measurement points along 20 measurement lines (Figure 12) of each sample. In order to define the mean hardness value for each measurement line, the total of 1140 individual hardness values were analysed. The calculated mean hardness values are shown in Figure 13. Variations of mean hardness values across the entire cross-section can be observed. An another common observation is that they are all greater than the prescribed minimum hardness value for a particular type (quality) of rail steel and the location of the measurement line in the crosssection of the rail head. A detailed analysis has shown that mean hardness values are on an average by $27 \%$ (sample 700 ) and $26 \%$ (sample 900A) higher than the minimum prescribed. Differences between samples 1 and 2 of the same rail steel quality (expressed as percentage) are shown in Figure 14. It is evident that differences are greater for samples 900A than for samples 700 . The difference in mean hardness values along the measurement line 14 for samples $900 \mathrm{~A}$ is as high as $25 \%$. In case of samples 700 , the biggest difference was observed along the line $20(15 \%)$. The mean difference in hardness values between samples $900 \mathrm{~A}-1$ and $900 \mathrm{~A}-2$ is $10 \%$, while the mean difference between samples $700-1$ and $700-2$ is $5 \%$.

Graphic representations of the variation of hardness values across the cross-section (Figures 15 and 16) were made

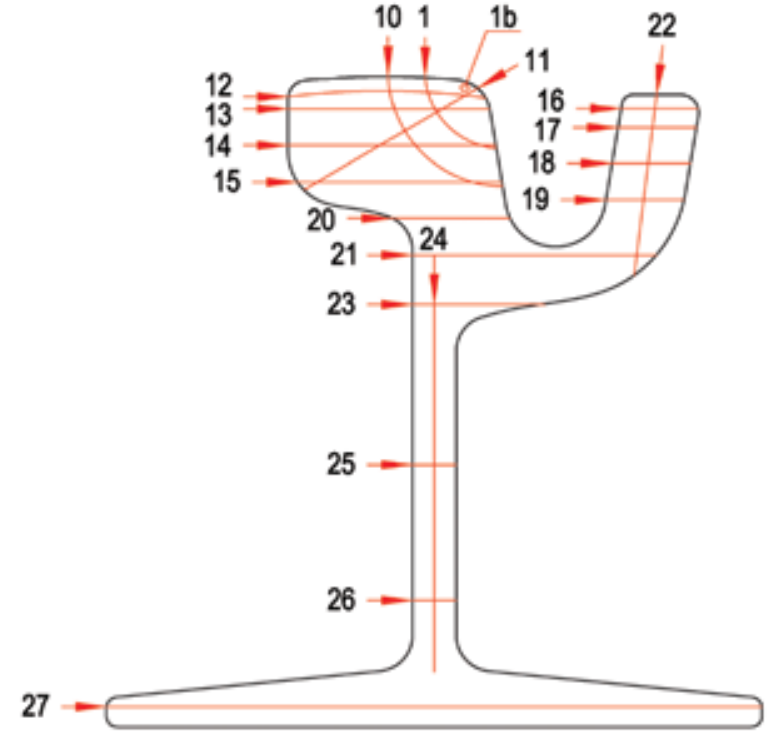

Figure 12. Hardness measurement lines at the rail cross-section

based on mean hardness values calculated along individual measurement lines. It can be seen from these figures that there is an extremely non-uniform distribution of hardness values across the rail cross-section. The values gradually decrease from the running surface, thru the rail head, to the web and rail base. Also, local areas of increased hardness values at the head-web and web-base transitions are clearly visible. 

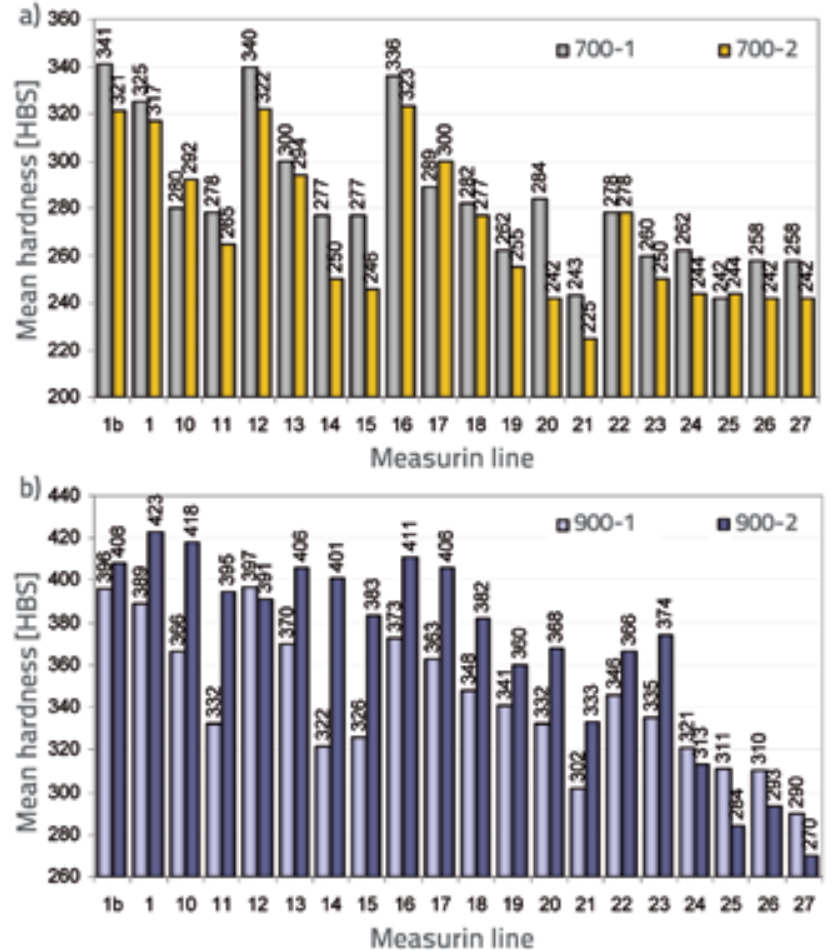

Figure 13. Mean hardness values: a) samples 700-1 and 700-2; b) samples $900 A-1$ and $900 A-2$

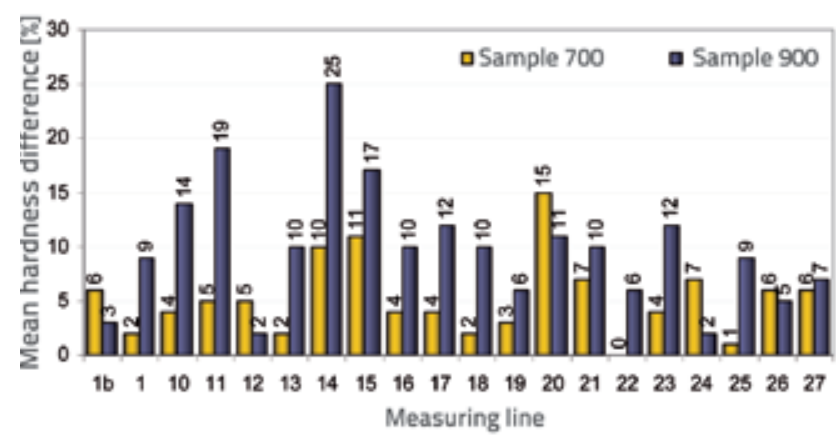

Figure 14. Differences in mean hardness values between samples 1 and 2 of the same rail steel quality

\subsection{Determination of tensile strength values}

Mean tensile strength values were calculated based on mean hardness values. Tensile strength $f_{u}$ is often cited to vary linearly with the Brinell hardness HBS, as follows:

$f_{u}=c \times H B S$

where the value of the correlation factor $c$ depends on the steel grade, and on the values and method of hardness

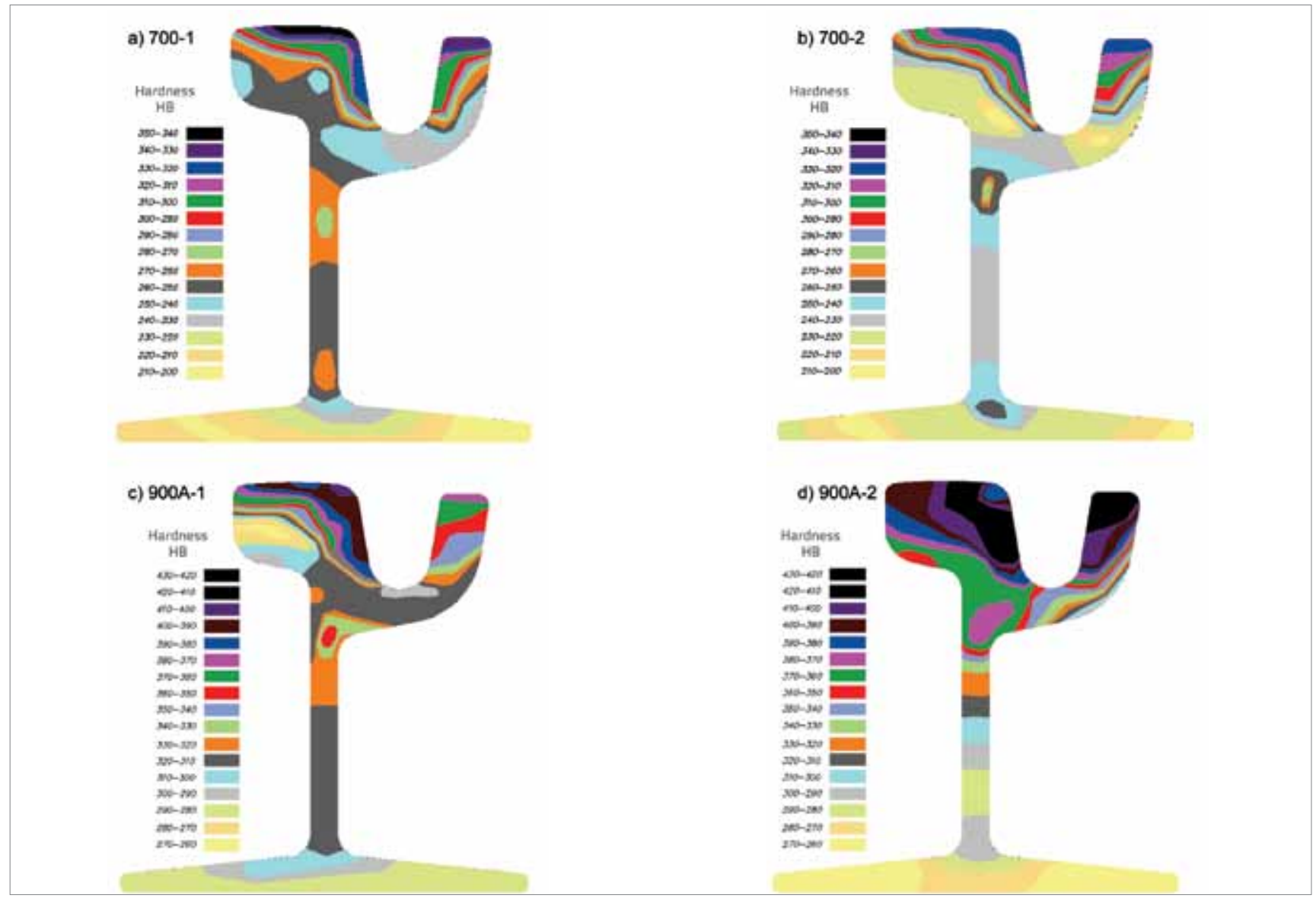

Figure 15. Hardness as a function of location in the rail cross-section: a) sample 700-1; b) sample 700-2; c) sample 900A-1; d) sample 900A-2 
determination. In this case, the correlation factor of $c=3.45$ was applied as it gives sufficient accuracy in case of steels whose tensile strength values vary between 450 and $2350 \mathrm{~N} /$ $\mathrm{mm}^{2}$ [10].

All measurement points at which hardness tests were conducted in order to define the tensile strength of rail steel are shown in Figure 16. In addition to previously defined measurement points 1 and 2 at the rail head cross-section, measurements were also conducted at five points located along the web and the base of the rails. These additional points were selected on the basis of graphic variation of hardness values (Figure 15 ) at which significant change in the hardness of steel occurred.

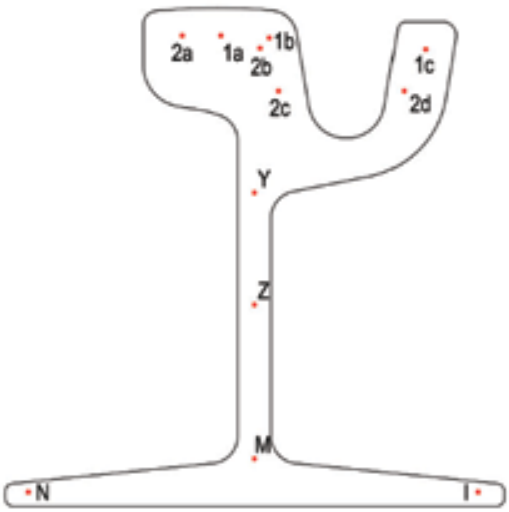

Figure 16. Hardness measurement points

The total of 200 measurements was conducted at all samples. Measurement results were subsequently processed in order to define mean hardness values for each steel grade, and mean values of tensile strength according to Eq. 1. Mean values calculated at individual measurement points of the rail cross-section are given in Tables 3 to 5 .

Table 3. Mean hardness and tensile strength values at measurement points $1 a, 1 b$, and 1c (section 1)

\begin{tabular}{|c|c|c|c|c|}
\hline \multirow{2}{*}{$\begin{array}{c}\text { Measurement } \\
\text { point }\end{array}$} & \multicolumn{2}{|c|}{ Sample 700 } & \multicolumn{2}{c|}{ Sample 900A } \\
\cline { 2 - 5 } & $\begin{array}{c}\text { Hardness } \\
{[\mathrm{HBS}]}\end{array}$ & $\begin{array}{c}\text { Tensile } \\
\text { strength } \\
{\left[\mathrm{N} / \mathrm{mm}^{2}\right]}\end{array}$ & $\begin{array}{c}\text { Hardness } \\
{[\mathrm{HBS}]}\end{array}$ & $\begin{array}{c}\text { Tensile } \\
\text { strength } \\
{\left[\mathrm{N} / \mathrm{mm}^{2}\right]}\end{array}$ \\
\hline $1 \mathrm{a}$ & 336 & 1160 & 360 & 1240 \\
\hline $1 \mathrm{~b}$ & 334 & 1153 & 388 & 1338 \\
\hline 1c & 338 & 1165 & 378 & 1304 \\
\hline Mean value & 336 & 1159 & 375 & 1295 \\
\hline
\end{tabular}

Table 4. Mean hardness and tensile strength values at measurement points $2 \mathrm{a}, 2 \mathrm{~b}, 2 \mathrm{c}$, and $2 \mathrm{~d}$ (section 2 )

\begin{tabular}{|c|c|c|c|c|}
\hline \multirow{2}{*}{$\begin{array}{c}\text { Measurement } \\
\text { point }\end{array}$} & \multicolumn{2}{|c|}{ Sample 700 } & \multicolumn{2}{c|}{ Sample 900A } \\
\cline { 2 - 5 } & $\begin{array}{c}\text { Hardness } \\
{[\mathrm{HBS}]}\end{array}$ & $\begin{array}{c}\text { Tensile } \\
\text { strength } \\
{\left[\mathrm{N} / \mathrm{mm}^{2}\right]}\end{array}$ & $\begin{array}{c}\text { Hardness } \\
{[\mathrm{HBS}]}\end{array}$ & $\begin{array}{c}\text { Tensile } \\
\text { strength } \\
{\left[\mathrm{N} / \mathrm{mm}^{2}\right]}\end{array}$ \\
\hline $2 \mathrm{a}$ & 324 & 1116 & 375 & 1293 \\
\hline $2 \mathrm{~b}$ & 327 & 1129 & 374 & 1289 \\
\hline $2 \mathrm{c}$ & 333 & 1148 & 378 & 1304 \\
\hline $2 \mathrm{~d}$ & 272 & 938 & 349 & 1206 \\
\hline Mean value & 314 & 1083 & 369 & 1273 \\
\hline
\end{tabular}

Table 5. Mean hardness and tensile strength values at other measurement points $Z, Y, M, N$, and I

\begin{tabular}{|c|c|c|c|c|}
\hline \multirow{2}{*}{$\begin{array}{c}\text { Measurement } \\
\text { point }\end{array}$} & \multicolumn{2}{|c|}{ Sample 700 } & \multicolumn{2}{c|}{ Sample 900A } \\
\cline { 2 - 5 } & $\begin{array}{c}\text { Hardness } \\
\text { [HBS] }\end{array}$ & $\begin{array}{c}\text { Tensile } \\
\text { strength } \\
{\left[\mathrm{N} / \mathrm{mm}^{2}\right]}\end{array}$ & $\begin{array}{c}\text { Hardness } \\
\text { [HBS] }\end{array}$ & $\begin{array}{c}\text { Tensile } \\
\text { strength } \\
{\left[\mathrm{N} / \mathrm{mm}^{2}\right]}\end{array}$ \\
\hline Z & 257 & 888 & 309 & 1065 \\
\hline Y & 233 & 804 & 341 & 1176 \\
\hline M & 264 & 911 & 321 & 1106 \\
\hline N & 231 & 796 & 302 & 1043 \\
\hline I & 238 & 821 & 315 & 1088 \\
\hline Mean value & 245 & 844 & 318 & 1096 \\
\hline
\end{tabular}

\section{Results of investigation}

According to [7], maximum deviation of measured hardness values from prescribed hardness values for a particular grade of rail steel, is $\pm 30 \mathrm{HBS}$. It was concluded by comparing hardness and tensile strength values shown in Table 3 to 5 with the ones prescribed by standards (Table 1 and 2) that the largest deviations in these values occurred at points across the rail head (Figure 17). The maximum deviation of the mean hardness values, and thus the calculated mean tensile strength values, from the prescribed minimum, was recorded at the measurement point $2 c$ of samples 700 , and at the measurement point $Y$ of rail web (samples 900A). Hardness and tensile strength values, significantly higher than the minimum ones 
defined by regulations, were measured at all measurement points along the cross section.

Comparison of prescribed minimum and mean values calculated for each section of the cross-section has shown that the mean values are by an average of $26 \%$ (samples 700) and $22 \%$ (samples 900A) higher than the prescribed ones. The results of mean tensile strength values calculated in cross-sections were satisfactory despite the great variability of hardness values.

a) Hardness difference

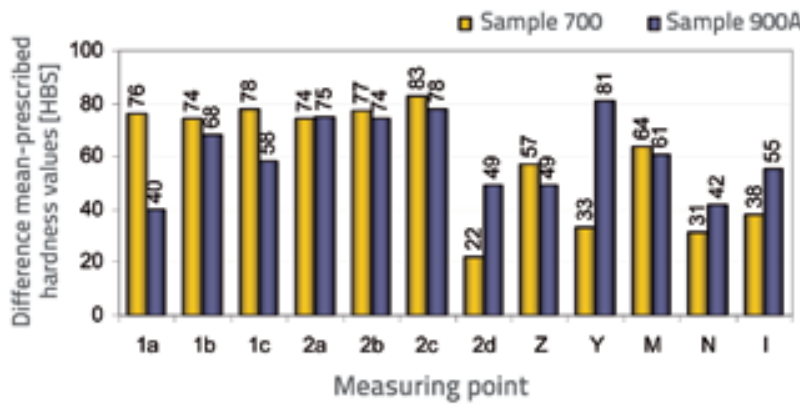

b) Tensile strength difference

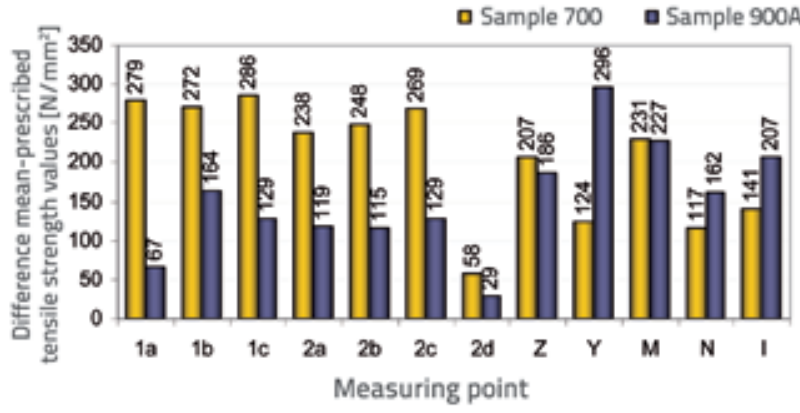

Figure 17. Difference between calculated mean values and prescribed minimum values of hardness and tensile strenght

\section{Discussion}

In response to difficulties that were manifested in form of $\mathrm{HH}$ rails cracking during the precurving process and accelerated rail head wear, measurements of steel hardness were made in order to find out whether the increased brittleness and intense wear of the rails are the consequence of poor mechanical properties of the rail steel.

Past research and practice have shown that rails with higher head hardness values should be used in order to reduce abrasion and corrugation, i.e. excessive track wear. By increasing the hardness of the rail head for 90 HBS the abrasive wear can be reduced by $50 \%$ [6] and, at the same time, by reducing corrugation, the noise and vibrations generated by irregularities on the wheel-rail contact surface can be diminished [11]. However, recent analyses of the $\mathrm{HH}$ rail use have shown controversial results $[1,12]$. In the course of rail use, the running surface of new rails assumes the shape that largely matches the wheel profile. This worn rail head profile has a larger contact area which causes a decrease in rail-wheel contact pressure. It can therefore be concluded that the $\mathrm{HH}$ rail, due to its greater resistance to wear, stays longer under unfavourable contact conditions, which may adversely affect its service life.

Hardness tests carried out at the cross-section of $\mathrm{HH}$ rails made of steel grade 700 and $900 \mathrm{~A}$, as described in this paper, point to extremely uneven distribution of hardness values along the cross section. The impact of such large hardness value deviations on the rail behaviour in track is unknown. It is assumed that this phenomenon may be associated either with conditions during production - rolling of steel rails, or with segregation and/or deformation of steel during its hardening [13]. Deficiencies in the process of rail head heat treatment, conducted in order to increase local hardness values, may also be responsible for inconsistent values of mechanical properties of steel along the rail head crosssection (hardness, and hence tensile strength). In general, any heat treatment leads to changes in steel microstructure. The difference in the warming and cooling (quenching) process, and the uneven distribution of temperature in different layers of the rail head (in cross section and along the rails), cause substantial variations in microstructure, which in turn results in local hardness and tensile strength differences. Experience has shown that such irregularities in the $\mathrm{HH}$ rail production process can cause very adverse martensitic microstructure in the heat-treated steel layer [14], which is responsible for the increase in brittleness and decrease in fracture toughness of rail steel attaining up to $25 \%[15]$.

\section{Conclusions}

Test results show that hardness values measured at the running surface of rail head samples 700 are satisfactory, while they are on an avearage $8 \%$ lower than the prescribed values in case of samples $900 \mathrm{~A}$. It was concluded that this deviation is negligible since tests were conducted on unused rail samples that were not subjected to cold forging, which is expected to increase the running surface hardness.

Hardness values measured across the rail cross-section are much larger ( $24 \%$ on an average) than the prescribed minimum, which leads to the conclusion that the cause of their poor in-service behaviour is not due to low hardness and tensile strength values of their steel. 
The rail cracking during precurving could be explained by reduced ductility and fracture toughness of rail head due to inhomogeneity along the cross-sectional microstructure, i.e. due to martensitic microstructure formation during thermal treatment of the rail head. It should be noted that a far more extensive and sophisticated analysis of rail steel microstructure should be conducted in order to confirm assertions and claims made in this paper.

\section{REFERENCES}

[1] Pointner, P.: High strength rail steels - The importance of material properties in contact mechanics problems, Wear, 265, pp. 1373-1379, 2008.

[2] Olofsson, U. \& Telliskivi, T.: Wear, plastic deformation and friction of two rail steels - a full-scale test and a laboratory study, Wear, 254, pp. 80-93, 2003.

[3] Lakušić, S. \& Ahac, M.: Vibrations on railway tracks (Chapter), Transport infrastructure management, ed. S. Lakušić, Faculty of Civil Engineering at Zagreb University, Zagreb, pp. 371-416, 2009. (in Croatian language)

[4] Lakušić, S., Rukavina, T. \& Dragčević, V.: Proposal for the value of permitted tolerance on width of grooved rails, Proceedings of the 8th International Conference on Computer Aided Design, Manufacture and Operation in the Railway and Other Advanced Mass Transit Systems (COMPRA/L 2002), eds. J. Allan, R.J. Hill, C.A. Brebbia, G. Sciutto and S. Sone, Lemnos, Greece, 12-14 June, 2002.

[5] Rails, Brochure published by Thyssen Schienen Technik, February 2000.

[6] Esveld, C.: Modern railway track, Second edition., TU-Delft, 2001.

[7] European Standard EN 13674-1:2004

\section{Acknowledgements}

Results presented in this paper were obtained in the scope of the research project 'Noise and Vibrations on Tram and Railway Tracks", financed by the Ministry of Science, Education and Sports of the Republic of Croatia. The rail samples were provided by the Zagreb Municipal Transit System - ZET, Ltd. The authors gratefully acknowledge their support and assistance.

[8] UIC CODE 860/1986, Technical specification for the supply of rails

[9] Oberbau-Richtlinien und Oberbau Zusatzrichtlinien (OR, OR-Z) des VDV für Bahnen nach der BOStrab, 1997.

[10] Pavlina, E.J. \& Van Tyne, C.J.: Correlation of yield strength and tensile strength with hardness for steels, Journal of Materials Engineering and Performance, 17(6), pp. 888-893, 2008.

[11] Falvey, A.: Track and trackform system - track and trackform report; Section 5 of Sydney metro network stage 2 reference design, Sidney, 2010

[12] Lee, K.M. \& Polycarpou, A.A.: Wear of conventional pearlitic and improved bainitic rail steels, Wear, 259 pp. 391-399, 2005.

[13] INNOTRACK GUIDELINE: Recommendation of, and scientific basis for, optimisation of switches \& crossings - part 2, Deliverable report D3.1.6, 2006.

[14] Zhan, X. \& Wang, S.: Research on the improvement of rail head hardening technology on railway, Proceedings of the Eastern Asia Society for Transportation Studies (5), pp. 263-271, 2005.

[15] Khourshid, A.M., Gan, Y.X. \& Aglan, H.A.: Microstructure origin of strength and toughness of a premium rail steel, Journal of Materials Engineering and Performance, 10(3) pp. 331- 336, 2001. 